\title{
Association between Silicone Breast Implants and Autoimmune Diseases
}

\section{Associação entre Implantes de Silicone Mamários e Doenças Autoimunes}

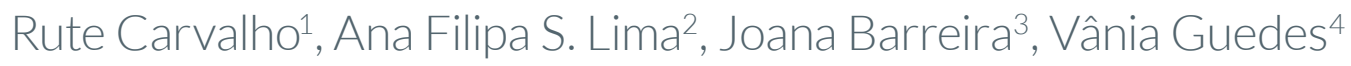

\begin{abstract}
BACKGROUND AND AIM: Silicone breast implants have, for a long time, been considered as biologically inert and harmless. However the relationship between silicone breast implants and the risk of autoimmune diseases has generated intense medical interest. The aim of our review is to summarize the data linking silicone breast implants and autoimmune diseases, including the most recent association with autoimmune/inflammatory syndrome induced by adjuvants (ASIA).

METHODS: The clinical research included articles from the last 16 years using the MeSH terms "breast implants" and "autoimmune diseases" and also the following terms: "autoimmune/inflammatory syndrome induced by adjuvants" and "Shoenfeld's syndrome". The Oxford 2011 Levels of Evidence was used to assign a level-of-evidence. Eligible articles included those who described a population of adult women (>17 years), which have breast implants versus women without implants. The clinical outcome measured was the development of an autoimmune disease. RESULTS: Of the 268 obtained articles, five matched eligibility criteria (one meta-analysis, two systematic reviews and two cohort studies). Results show that although studies could not confirm an association between silicone breast implants and classical autoimmune diseases, a few studies demonstrated an association between implants and undefined symptoms such as fatigue, arthralgia, myalgia and cognitive symptoms, which resembled a newly introduced syndrome, known as ASIA.

CONCLUSIONS: Evidence remains inconclusive about any association between silicone breast implants and classical autoimmune diseases. ASIA seems to be linked to previous exposition to an adjuvant such as silicone. However, we will need better evidence from large studies with accurate methodology to determine whether any true association exists between ASIA syndrome and silicone breast implants.
\end{abstract}

KEYWORDS: Autoimmune Diseases; Autoimmunity; Breast Implantation/adverse effects; Silicones/adverse effects; Silicone Gels/adverse effects 


\section{RESUMO}

INTRODUÇÃO E OBJETIVOS: Durante muito tempo, os implantes mamários foram considerados como dispositivos médicos inócuos. No entanto, ao longo dos últimos anos, a sua possível associação com doenças autoimunes tem gerado um debate científico crescente, sobretudo no que diz respeito à relação com a síndrome autoimune induzida por adjuvantes (ASIA). $O$ objetivo desta revisão é sintetizar os dados atualmente disponíveis que relacionam estas entidades.

MÉTODOS: Foi realizada uma pesquisa bibliográfica usando os termos MeSH "breast implants" e "autoimmune diseases" e também os termos "autoimmune/inflammatory syndrome induced by adjuvants" e "Shoenfeld's syndrome". A escala de "Oxford 2011 Levels of Evidence" foi usada para atribuir um nível de evidência. Os artigos selecionados incluíram os que descreviam uma população de mulheres adultas com implantes mamários versus mulheres sem implantes. O outcome clínico avaliado foi o desenvolvimento de uma doença autoimune.

RESULTADOS: Dos 268 artigos obtidos, cinco cumpriam os critérios de inclusão (uma meta-análise, duas revisões sistemáticas e dois estudos coorte). Os resultados mostram que, embora os estudos não comprovem uma associação entre implantes mamários de silicone e doenças autoimunes clássicas, alguns demonstraram uma associação entre os implantes e sintomas inespecíficos de uma síndrome recentemente introduzida, denominada ASIA.

CONCLUSÕES: A evidência disponível sobre a associação entre implantes mamários e o desenvolvimento de uma doença autoimune clássica permanece inconclusiva. A ASIA parece estar relacionada a uma exposição prévia a um adjuvante, nomeadamente ao silicone. Contudo, são necessários estudos mais longos e com metodologias mais rigorosas para esclarecer a associação entre implantes mamários de silicone e o desenvolvimento de ASIA.

PALAVRAS-CHAVE: Autoimunidade; Doenças Autoimunes; Gel de Siliconelefeitos adversos; Implantes Mamários/efeitos adversos; Silicones/efeitos adversos

\section{INTRODUCTION}

Breast implants (BI) have for a long time, been considered as biologically inert and harmless. However, from 1992 to 2006, the Food and Drug Administration (FDA) restricted their use due to controversy about their safety. ${ }^{1}$

When the FDA approved silicone gel-filled $\mathrm{BI}$ in the United States, in 2006, it recognized that there were limited data on rare events and long-term outcomes, so required each company to design and conduct post-approval studies as conditions of approval. ${ }^{2}$ Local complications and adverse outcomes included capsular contracture, reoperation, implant rupture, wrinkling, asymmetry, scarring, pain and infection; however these complications were consistent with those noticed at the time of the approval. ${ }^{2,3}$ Implant removal was also described and the longer the women had silicone gel-filled $\mathrm{BI}$, the more likely was to experience local complications or adverse outcomes. ${ }^{2}$

In what concerns to extended complications, although an association with systemic diseases was never established, women continuously blamed implants for their unexplained symptoms. ${ }^{3}$ The question whether silicone $\mathrm{BI}$ can cause serious systemic health problems has often been posed but seldom thoroughly answered. ${ }^{3}$

According to the FDA Update on the Safety of Silicone Gel-Filled Breast Implants, over studies with 8 to 10 years of follow-up, there have been some diagnoses of connective tissue disease (CTD) and autoimmune or rheumatic diseases. These included cases of fibromy- algia, Raynaud's syndrome (RS), rheumatoid or inflammatory arthritis, systemic lupus erythematosus (SLE), thyroid-related disease, miscellaneous and unspecified CTD cases. Follow-up rates were considered low, so the FDA recognized that these studies had limitations, and did not provide the necessary data to definitively answer questions about rare associations and that the current literature did not support an association between CTD and silicone gel-filled BI. ${ }^{2}$ However, a few studies demonstrated an association between implants and undefined symptoms such as fatigue, arthralgia, myalgia and cognitive symptoms. ${ }^{3}$

Other authors reported a symptom pattern in patients with silicone BI that mimic autoimmune. ${ }^{3}$ In the 1990 s this even lead to the introduction of a new disease called "siliconosis" or "silicone reactive disorder" with symptoms such as memory loss, fever morning stiffness, paraesthesia, hair loss, sweating and joint pain. ${ }^{3}$

Later, a syndrome called "autoimmune/inflammatory syndrome induced by adjuvants" (ASIA) or Shoenfeld's syndrome was introduced. ${ }^{3}$ This autoimmune/inflammatory syndrome was proposed on 2011 by Shoenfeld et al and includes five conditions linked to previous exposure to an adjuvant substance, one of which could be silicone, suggesting an association between environmental factors and induction of autoimmunity and loss of tolerance. ${ }^{4} \mathrm{~A}$ long time after the first description of this relationship, Colaris MJ et al recognized the development of a specific entity that cannot be classified as a classic CTD, thus proposing label these patients as suf- 
fering from ASIA due to 'Silicone Implant Incompatibility Syndrome' (SIIS). ${ }^{5}$ In 2013, Tervaert JW et al described a case series of 32 women with silicone BI who had silicone implant incompatibility syndrome and complaints fulfilling the diagnostic criteria of ASIA. Furthermore, 17 of them were classified as suffering from a systemic autoimmune disease and seven patients from an organ-specific autoimmune disease. ${ }^{6}$

Shoenfeld's criteria for ASIA include four major and four minor criteria, and patients were considered having the syndrome when either two major or one major and two minor criteria were present. Therefore, major criteria were: exposure to an external stimulus (infection, vaccine, silicone, adjuvant) prior to clinical manifestations; the appearance of 'typical' clinical manifestations: myalgia, myositis or muscle weakness, arthralgia and/or arthritis, chronic fatigue, unrefreshing sleep or sleep disturbances, neurological manifestations (especially associated with demyelination), cognitive impairment, memory loss, pyrexia or dry mouth; the removal of inciting agent induces improvement; typical biopsy of involved organs. The four minor criteria established were: the appearance of autoantibodies or antibodies directed at the suspected adjuvant; other clinical manifestations (i.e. irritable bowel syndrome); specific HLA (i.e. HLA DRB1, HLA DQB1); evolvement of an autoimmune disease (i.e. multiple sclerosis, systemic sclerosis). ${ }^{5}$

There are some authors that recognize the association, but they consider a definition of those women who might harbor an increased risk for this disease. They believe that there are four groups of patients sharing predisposition to the development of silicone-induced ASIA: patients with prior documented autoimmune reaction to an adjuvant (e.g. vaccination); patients with established autoimmune conditions; patients with history of allergic conditions/atopic disorders; and individuals who are prone to develop autoimmunity (genetic predisposition and/or relevant environmental triggers). ${ }^{7}$

Although most studies could not undoubtedly confirm or deny an association between implants and CTD or autoimmune diseases, this relationship remains under intense debate. ${ }^{3,8}$

Due to the controversy about their safety, the authors decided to do a systematic review to summarize the data linking silicone $\mathrm{BI}$ and autoimmune diseases, including the most recent association with ASIA.

\section{METHODS}

A clinical research was conducted including articles from the last 16 years, in Portuguese and English languages, using the MeSH terms "breast implants" and "autoimmune diseases" and also the following terms: "ASIA - autoimmune/inflammatory syndrome induced by adjuvants" and "Shoenfeld's syndrome".

The literature searches were done in MEDLINE databases, National Clearinghouse, Canadian Medical Association Practice Guidelines InfoBase, Guidelines Finder of the National Electronic Library for Health in the British NHS, Database of Abstracts of Reviews of Effectiveness - Centre for Reviews and Dissemination, Bandolier and The Cochrane Library.

We used the Oxford 2011 Levels of Evidence to assign a level-of-evidence (LE). Eligible articles included those who described a population of adult women ( $>17$ years), which have breast implants versus women without implants. The clinical outcome measured was the development of an autoimmune disease, including the most recent linking with ASIA or "Shoenfeld's syndrome".

Of the 268 obtained articles, five matched eligibility criteria (one meta-analysis, two systematic reviews and two cohort studies). Of these, 263 were excluded after title reading ( $n=192)$, abstract reading $(n=29)$ and since they were repeated articles ( $n=42)$ (Fig. 1).

SYNTHESIS OF RESULTS: 58 studies (in five publications) met eligibility criteria. Therefore, the relation between silicone BI and autoimmune diseases (such as rheumatoid arthritis (RA), Sjögren's syndrome (SjS), RS, dermatomyositis and polymyositis, fibromyalgia, sarcoidosis, SLE, CTD) is a question that reveals different conclusions obtained so far with a consensus trend towards no increased risk of this association, which can lead to a lack of a fully answer to this question. Thus, in recent years, silicone prostheses were possibly associated with ASIA,

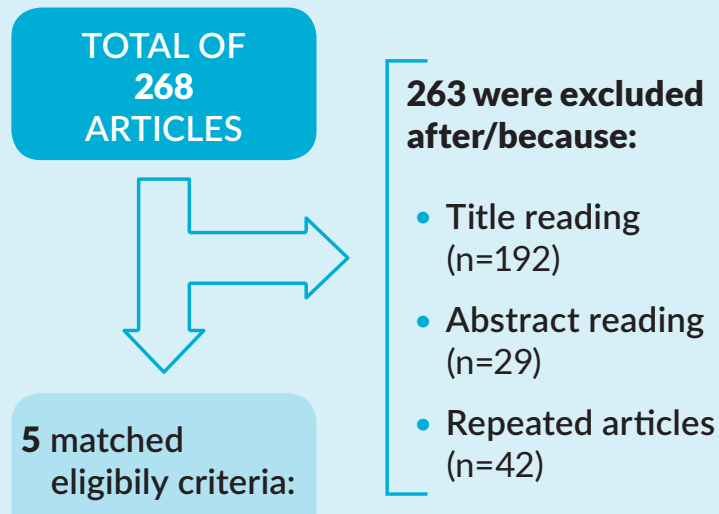

1 Meta-analysis

2 Systematic reviews

1 Cohort studies

FIGURA 1. Selected articles fluxogram. 
in some cases even with life-threatening outcomes. However, the evidence between this association remains inconclusive and several more studies are needed to assign a better LE.

RISK OF BIAS ACROSS STUDIES: studies included had differences in study design, clinical endpoints, definitions and patient populations. Yet, the evidence was most frequently not specific to silicone BI. Last but not least, low patient follow-up rates limited drawing definitive conclusions.

No additional analyses were done.

\section{RESULTS}

Janowsky EC et al ${ }^{8}$ study included nine cohort studies (CS), nine case-control studies (CCS) and two cross-sectional studies (CSC). A meta-analysis of the results of these articles was conducted, with and without adjustment for confounding factors and a separate analysis restricted to studies of silicone BI. It was also estimated the annual number of new cases of connective-tissue disease that could be a consequence of the use of BI. The CS, the CSC and one CCS evaluated multiple diseases outcomes (Table 1). Several diseases were studied: RA, SLE, scleroderma or systemic sclerosis (SS), SjS, dermat- omyositis or polymyositis, all definitive connective tissue combined and a category of other autoimmune or rheumatic conditions. Rheumatic conditions included undifferentiated CTD or mixed CTD that did not fulfill the diagnostic criteria of classic autoimmune diseases or signs and symptoms of autoimmune or rheumatic conditions, such as joint pain, swelling or both.

Janowsky EC et al used several techniques of meta-analyses which included exact methods (unadjusted analysis) and approximate, large-sample methods (adjusted analysis). These authors also considered study results that included only silicone-gel-filled implants. There is no evidence, in either analysis of unadjusted odds ratios or the analysis of adjusted relative risks (RR), excluding the results of the study by Hennekens et al, ${ }^{9}$ of a significantly increased risk of any specific CTD, all definite CTD combined or other autoimmune or rheumatoid conditions, as it can be seen on Table 1.

Nor was there evidence of significantly increased risk in the unadjusted analyses or in analysis restricted to silicone gel Bl. The meta-analyses focusing solely on silicone-gel BI produced lower summary estimates of the adjusted RR for all diseases than did the analysis based on all types of $\mathrm{BI}$. It can be noticed that relative risk for

TABLE 1. Meta-analysis results.

\begin{tabular}{|c|c|c|c|c|c|}
\hline Reference & Included studies & Intervention & Results & Conclusions & LE \\
\hline $\begin{array}{l}\text { Janowsky EC } \\
\text { et al }(2000)^{8} \\
16 \text { studies }\end{array}$ & $\begin{array}{l}\text { - Data collected: } \\
1966 \text { to } 1998 \\
\text { - } 9 \text { cohort studies } \\
\text { - } 9 \text { case-control studies } \\
\text { - } 2 \text { cross-sectional studies } \\
\text { - Diseases studied: } \\
\text { rheumatoid arthritis } \\
\text { (RA), systemic lupus } \\
\text { erythematosus (SLE), } \\
\text { scleroderma or systemic } \\
\text { sclerosis (SS), Sjögren's } \\
\text { syndrome (SjS), } \\
\text { dermatomyositis or } \\
\text { polymiositis (D); } \\
\text { all definitive connective } \\
\text { tissues combined } \\
\text { and a category of } \\
\text { other autoimmune or } \\
\text { rheumatic conditions. }\end{array}$ & $\begin{array}{l}\text { Conduction of } \\
\text { meta-analyses to } \\
\text { investigate the relation } \\
\text { between Bl and the risk } \\
\text { of autoimmune } \\
\text { conditions or connective } \\
\text { tissue diseases. } \\
\text { Diseases variables: } \\
\text { presence or absence of all } \\
\text { of the } 5 \text { connective tissue } \\
\text { diseases (CTD) and all } \\
\text { diseases combined and } \\
\text { other autoimmune or } \\
\text { rheumatic conditions. } \\
\text { Exposure variables: } \\
\text { presence or absence } \\
\text { of any type of BI } \\
\text { A separate analysis } \\
\text { was conducted for silicone } \\
\text { gel Bl. }\end{array}$ & $\begin{array}{l}\text { There is no evidence that } \\
\text { BI were associated } \\
\text { with a significantly } \\
\text { increased risk of any CTD: } \\
\text { - RA: relative risk (RR) } \\
\text { 1.04; } 95 \% \text { confidence } \\
\text { interval (CI) 0.72-1.51 } \\
\text { - SLE: RR 0.65; 95\% } \\
\text { CI 0.35-1.23 } \\
\text { - SS: RR 1.01; 95\% } \\
\text { CI 0.59-1.73 } \\
\text { - SjS: RR 1.42; 95\% } \\
\text { CI 0.65-3.11 } \\
\text { - D: RR 1.51; 95\% } \\
\text { CI 0.97-2.37 } \\
\text { - All combined: } \\
\text { RR 0.80; } \\
95 \% \text { CI 0.62-1.04 } \\
\text { - Other conditions: } \\
\text { RR 0.96; } 95 \% \\
\text { Cl 0.74-1.25 } \\
\text { Nor was there evidence } \\
\text { of significantly increased } \\
\text { risk in the unadjusted } \\
\text { analyses or in analysis } \\
\text { restricted to silicone gel BI. }\end{array}$ & $\begin{array}{l}\text { There was no evidence } \\
\text { of an association between } \\
\text { Bl in general, or silicone } \\
\text { gel Bl, and any of the } \\
\text { individual CTD, all diseases } \\
\text { combined or other } \\
\text { autoimmune or rheumatic } \\
\text { conditions. } \\
\text { The elimination of implants } \\
\text { would not be likely to } \\
\text { reduce the incidence of } \\
\text { CTD. }\end{array}$ & 2 \\
\hline
\end{tabular}

Legend: BI - breastimplants; CTD -connective tissue disease; Cl-confidence interval; D-dermatomyositis or polymiositis; RA-rheumatoid arthritis; RR-relative risk; SjS-Sjögren's syndrome; SLE-systemic lupus erythematosus; SS-scleroderma or systemic sclerosis. 
SjS was high (RR: 1.42; 95\% confidence interval (CI): 0.65 to 3.11 ) but this diagnosis requires salivary-gland biopsy and this information is unknown, so it may have bias in estimated adjusted RR's size.

Authors concluded that there was no evidence of an association between $\mathrm{BI}$ in general, or silicone-gel $\mathrm{BI}$, and any of the individual CTD, all CTD combined or other autoimmune or rheumatic conditions. BI have a minimal effect on the number of women in whom CTD develop and the elimination of implants would not be likely to reduce the incidence of CTD.

The study of Balk EM et al ${ }^{1}$ had the purpose to systematically review the literature regarding specific long-term health outcomes in women with silicone gel BI, including: cancer, connective tissue, rheumatologic and autoimmune diseases, neurologic diseases, reproductive issues (including lactation), offspring issues and mental health issues (depression and suicide) (Table 2). Studies of any longitudinal design were included and compared women with and without BI. These articles included women with any history of silicone gel BI (excluding injected silicone), silicone tissue expanders and recall implants produced by Poly Implant Prothèse. This review took place under contract with Plastic Surgery Foundation.

Of the 32 studies included, we will just examine the ones related to CTD. These studies found an increased risk for RA and SjS, and possibly RS, but no associations with others CTD. Nevertheless, the evidence is inadequate to determine whether silicone gel BI affect the risk for these diseases because few analysis were adequately adjusted for many confounders. The results are summarized on Table 2.

These authors concluded that, despite numerous studies reporting on the risk of many diseases and conditions, evidence was insufficient for an association between BI and any health outcome, including CTD. Furthermore, most of studies analyzed all BI, so their findings are not specific for silicone gel BI. No outcome had at least two adequately adjusted studies that yielded consistent estimates of associations. Owing the flaws and inconsistencies among the studies reviewed, further investigation is required whether any true association exist between silicone gel BI and long term health outcomes.

The aim of the Luis J. Jara et al ${ }^{4}$ study was to systematically review the literature of severe ASIA cases. Articles published from 2011 to 2016 were included and this was the first study which analyzed all cases published of ASIA with severe manifestations. Severe ASIA was arbitrarily defined as major organ involvement, life-threatening conditions, intensive treatment, disability, hospitalization and outcome (survival and death).
They identified 4479 ASIA cases, 305 of which fulfilled arbitrary criteria of severe ASIA and 11 resulted in death. The majority of severe ASIA cases were related to human papillomavirus (HPV) vaccine, silicone, influenza vaccine and mineral oil injections. We will just examine silicone related results (Table 2). The most affected organs were skin (17.7\%), musculoskeletal tissue (14.43\%), thyroid (13.77\%), nervous system (13.22\%) and gastrointestinal system (12.79\%). Death causes related on this study were due to mineral oil injections (three patients), silicone (one patient which committed suicide) and seven due to HPV vaccine (not specified). The majority of severe ASIA cases were associated with silicone BI followed by HPV vaccine. The new case reports and cohort studies suggest an association between silicone BI with ASIA development, particularly after prosthesis rupture. In Luis J. Jara et al study, of the 130 ASIA cases related to silicone, 13 were considered severe ASIA, eight of these had prosthesis rupture and one committed suicide.

The authors concluded that efforts should be done to identify connections between adjuvants, autoimmunity and autoimmune diseases, whereas there's an increase in severe and life-threatening ASIA cases.

Maijers $M C$ et $a^{3}$ conducted a descriptive cohort study and their aim was to collect a cohort of women with silicone $\mathrm{BI}$ and unexplained systemic symptoms to identify a possible pattern and compare it with ASIA (Table 3). They included 80 women with silicone BI and unexplained systemic symptoms. All of them were examined by experienced consultant physicians and interviewed. Also, chest radiography (to exclude sarcoidosis) and laboratory tests were performed (C-reactive protein, hemoglobin, thrombocytes, leucocytes with differentiation, renal function and liver enzymes). The median age of women established was 47 years, $89 \%$ had silicone $\mathrm{Bl}$ for cosmetic reasons and the median total exposure time to silicone was 14.5 years. Most women (75\%) with silicone BI and unexplained systemic symptoms had pre-existent allergy prior to implantation, suggesting that intolerance to silicone or other substances in the implants might cause these symptoms. After a symptom-free period of years (median of 4.5 years), 65\% developed systemic symptoms, most frequently fatigue, neurasthenia, joint pain, muscle pain, morning stiffness, night sweats and dyspnea. When classified according to the ASIA criteria, all women had at least two major criteria and 79\% of women even fulfilled three or more typical clinical criteria ASIA manifestations. Because of the unexplained symptoms, 52 out of 80 women had an explantation of their BI. Among these 52 women, 36 reported a significant decrease of their symptoms, whereas nine of these 36 women stated that their symptoms had completely disappeared.

These study results align the hypothesis that silicone 
TABLE 2. Systematic reviews results.

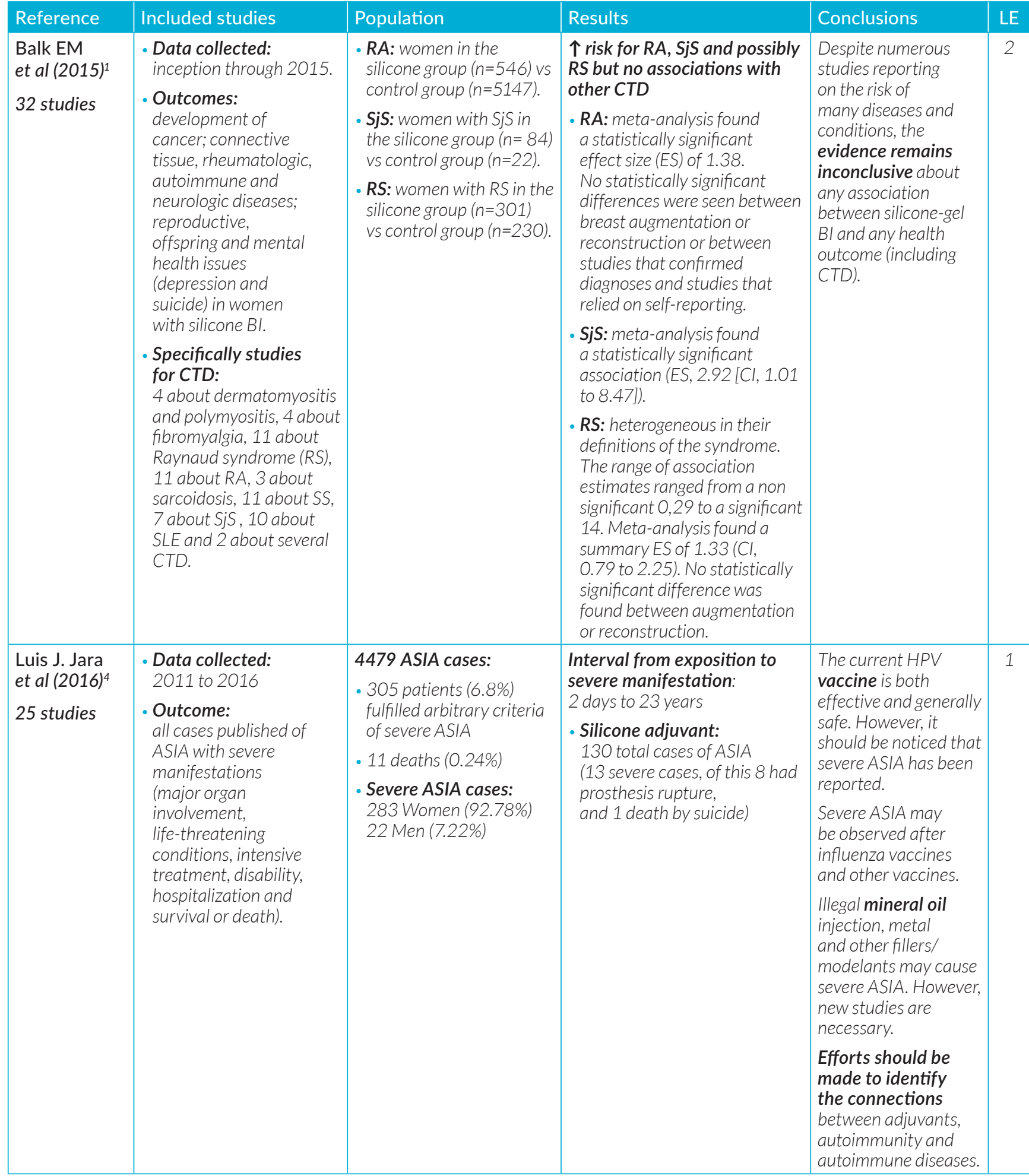

Legend: ASIA - autoimmune/inflammatory syndrome induced by adjuvants; $\mathrm{BI}$ - breast implants; CI - confidence interval; CTD - connective tissue disease; HPV - human papillomavirus; RA - rheumatoid arthritis; RS - Raynaud syndrome; SjS - Sjögren's syndrome; SLE - systemic lupus erythematosus; SS - scleroderma or systemic sclerosis.

or other chemical substances in the implants may cause systemic symptoms in women with atopy or hyperimmune state. Although they had noticed a significant improvement in many patients after explantation, these results should be interpreted with caution because there was no control group. Therefore, in conclusion physicians should recognize this pattern and consider referring patients for explantation.
Colaris et al ${ }^{5}$ cohort study compared 100 patients with ASIA criteria due to SIIS (the Maastricht cohort) diagnosed in 2014, with the Baylor College cohort (composed of 100 patients with adjuvant breast disease diagnosed between 1985 and 1992) and 18 other large cohorts of patients. The goal was to determine whether the spectrum of silicone-related disease changed during the last 30 years and whether ASIA due to SIIS was actually 
the same disease as the previously described adjuvant breast disease (Table 3).

In the Maastricht cohort, they analysed prospectively patients who developed complaints after receiving silicone gel-filled BI, using the Shoenfeld's criteria for the diagnosis of ASIA. The first consecutive hundred patients who fulfilled these criteria (two major or one major and two minor criteria) were included in this study. If explantation of silicone implants was performed, patients were reassessed to document possible changes of their clinical manifestations. This group was compared with the cohort described by Shoaib et al in 1994, constituted of 100 women with adjuvant breast disease, due to silicone breast implants or silicone fluid injections. ${ }^{10}$

They concluded that the clinical manifestations between the cohorts were more or less identical, describing comparable frequencies of chronic fatigue, cognitive impairment, pyrexia, sicca complaints and severe neurological manifestations (especially associated with demyelination). However, the authors found significant differences between the two cohorts regarding myalgia, myositis or muscle weakness, arthralgia and/or arthritis, livedo reticularis and the occurrence of Raynaud's phenomenon, possibly due to differences in the diagnosis work-up. In the 2014 cohort, they also diagnosed 34 patients with an autoimmune disease (CTD, vasculitis, RA and others), whereas in the Baylor College cohort they did not describe any autoimmune disease. Besides, in the Maastricht cohort, 27 of 54 patients who underwent explantation of their silicone $\mathrm{Bl}$ experienced improvement of their clinical manifestations, with a relapse of complaints after several weeks in seven patients. In the Baylor College cohort, 96 patients underwent explantation of the implant, but they did not describe the evolution of complaints. After comparing the Maastricht cohort and the Baylor College cohort with the 18 other large cohort studies, they concluded that a great similarity in complaints exists in all studies.

Author's findings suggest that, even with changes in the silicone implants composition in recent years, silicone remained a chronic stimulus to the immune system resulting in similar clinical manifestations between these cohorts. However, is still not clear if silicone BI are safe.

TABLE 3. Cohort studies results.

\begin{tabular}{|c|c|c|c|c|c|}
\hline Reference & Population & Intervention & Results & Conclusions & LE \\
\hline $\begin{array}{l}\text { Maijers MC } \\
\text { et al }(2013)^{3}\end{array}$ & $\begin{array}{l}\text { - Data collection: } \\
\text { March } 2012 \text { - } 2013 \\
\text { - Purpose: } \\
\text { to collect a cohort } \\
\text { of women (n=80) } \\
\text { with silicone BI and } \\
\text { unexplained systemic } \\
\text { symptoms to identify } \\
\text { a possible pattern and } \\
\text { compare this with } \\
\text { "autoimmune syndrome } \\
\text { induced by adjuvants } \\
\text { (ASIA)". 75\% of them } \\
\text { reported preexistent } \\
\text { allergies. }\end{array}$ & $\begin{array}{l}\text { - All women included } \\
\text { where examined, } \\
\text { interviewed, made } \\
\text { chest radiography } \\
\text { and laboratory tests. }\end{array}$ & $\begin{array}{l}\text {-After a symptom-free } \\
\text { period of years, } 65 \% \\
\text { developed systemic } \\
\text { symptoms. } \\
\text { - All had at least } \\
2 \text { major ASIA criteria } \\
\text { and } 79 \% \text { fulfilled } \geq 3 \\
\text { typical clinical ASIA } \\
\text { manifestations. } \\
\text { - After explantation, } \\
36 \text { out of } 52 \text { women } \\
\text { experienced a significant } \\
\text { reduction of symptoms. }\end{array}$ & $\begin{array}{l}\text { Silicone in BI may cause } \\
\text { systemic symptoms in } \\
\text { women with atopy or } \\
\text { hyperimmune state. } \\
\text { Physicians should recognize } \\
\text { this pattern and consider } \\
\text { referring patients for } \\
\text { explantation. }\end{array}$ & 3 \\
\hline $\begin{array}{l}\text { Colaris MJL, } \\
\text { et al }(2016)^{5}\end{array}$ & $\begin{array}{l}\text { - Data collection: } \\
\text { Jan - Oct } 2014 \\
\text { - Purpose: } \\
\text { to compare } 100 \\
\text { patients with ASIA (the } \\
\text { Maastricht cohort) } \\
\text { with } 100 \text { patients with } \\
\text { adjuvant breast disease } \\
\text { (the Baylor College } \\
\text { cohort, } 1985 \text { and 1992) } \\
\text { and } 18 \text { otherlarge } \\
\text { cohorts of patients, } \\
\text { in order to determine } \\
\text { whether the spectrum } \\
\text { of silicone-related disease } \\
\text { changed during the last } \\
30 \text { years. }\end{array}$ & $\begin{array}{l}\text { - Comparison of the } \\
\text { Shoenfeld's criteria for } \\
\text { the diagnosis of ASIA } \\
\text { between the cohorts. }\end{array}$ & $\begin{array}{l}\text { - The clinical } \\
\text { manifestations } \\
\text { between the cohorts } \\
\text { were more or less } \\
\text { identical, with } \\
\text { comparable frequencies } \\
\text { of major criterion of the } \\
\text { ASIA syndrome. } \\
\text { - In the } 2014 \text { cohort were } \\
\text { diagnosed } 34 \text { patients } \\
\text { with an autoimmune } \\
\text { disease (connective } \\
\text { tissue disease, vasculitis, } \\
\text { rheumatoid arthritis and } \\
\text { others). }\end{array}$ & $\begin{array}{l}\text { - Even with changes in } \\
\text { the silicone implants } \\
\text { composition in recent } \\
\text { years, silicone remained } \\
\text { a chronic stimulus to the } \\
\text { immune system. } \\
\text { - It is still not clear if } \\
\text { silicone breast implants } \\
\text { are safe. }\end{array}$ & 3 \\
\hline
\end{tabular}

Legend: ASIA - autoimmune/inflammatory syndrome induced by adjuvants; BI - breast implants. 
Synthesis of results: Janowsky EC et al meta-analysis showed no evidence of an association between breast implants and a significant increase in the summary adjusted RR of individual CTD (RA, 1.04 (95\% Cl, 0.72 to 1.51); SLE, 0.65 ( $95 \% \mathrm{Cl}, 0.35$ to 1.23); scleroderma or systemic sclerosis, 1.01 (95\% Cl, 0.59 to 1.73); and SjS, $1.42(95 \% \mathrm{Cl}, 0.65$ to 3.11$))$.

Balk EM et al systematic review of 32 studies showed for most outcomes there was at most only a single adequately adjusted study, which usually found no significant associations. There were possible associations with increased risks for RA, SjS and RS.

The systematic review of Luis J. Jara et al was performed investigating severe ASIA cases. From 2011 to 2016, they identified 4479 ASIA cases, of them 305 fulfilled arbitrary criteria of severe ASIA including 11 deaths. The authors concluded that efforts should be done to identify connections between adjuvants, autoimmunity and autoimmune diseases, whereas there's an increase in severe and life-threatening ASIA cases.

In the cohort study of Maijers MC et al 80 women were included, of which $75 \%$ reported pre-existent allergies. After a symptom-free period of years, a pattern of systemic symptoms developed, which included fatigue, neurasthenia, myalgia, arthralgia and morning stiffness in more than $65 \%$ of women. All had at least two major ASIA criteria and $79 \%$ fulfilled $\geq 3$ typical clinical ASIA manifestations.

The cohort study of Colaris et al included two cohort groups: one with ASIA due to silicone implant incompatibility syndrome diagnosed in 2014 and the other with one hundred historical patients with adjuvant breast disease diagnosed between 1985 and 1992. Clinical manifestations between these studies were comparable.

Risk of bias across studies: some studies refer selection bias, since included women with $\mathrm{Bl}$ and symptoms sought for medical care. Others refer that publication bias could be considered because studies that found no association were less likely to be published. Other considered bias to be related to the presence of inadequately adjusted studies, the unknown information regarding the diagnosis of specific diseases, (e.g. SjS which requires salivary-gland biopsy), the absence of control groups and small patient follow-up rates. Studies had yet differences in study design, clinical endpoints, definitions and patient populations.

\section{DISCUSSION}

We used techniques of systematic review to evaluate the existing studies of an association between breast implants and autoimmune diseases.
The results show that although studies could not confirm an association between silicone BI and classical autoimmune diseases, a few studies demonstrated an association between implants and undefined symptoms such as fatigue, arthralgia, myalgia and cognitive symptoms, which resembled a newly introduced syndrome, known as ASIA.

In the five included articles the evidence is not consensual.

Related to classical autoimmune diseases, the meta-analysis of Janowsky EC et a ${ }^{8}$ concluded that there was no evidence of an association between silicone-gel BI and any of the autoimmune diseases.

The systematic review of Balk EM et al ${ }^{1}$ showed an increased risk for RA, SjS and possibly RS but no associations with other diseases. Related to ASIA, the systematic review of Luis J. Jara et a ${ }^{4}$ suggested an association between silicone BI with ASIA development, particularly after prosthesis rupture.

The cohort study of Maijers MC et $a^{3}$ showed that most women with silicone $\mathrm{BI}$ and unexplained systemic symptoms had pre-existent allergy prior to implantation, suggesting the hypothesis that silicone, or other chemical substances in the implants, may cause systemic symptoms in women with atopy or hyperimmune state. The cohort study of Colaris et al ${ }^{5}$ reported a group of patients who developed complaints related to silicone BI, with the diagnostic criteria of ASIA.

However, the studies included in our review have some limitations. First of all, meta-analysis and systematic reviews are based on observational studies that are more susceptible to bias than clinical trials.

One other potential limitation of this review is the design of some studies, as women with silicone BI and unexplained symptoms visited the clinical on their own request, leading to selection bias.

Information on potential confounders of the association between $\mathrm{BI}$ and CTD was also incomplete in many studies. Specific genetic markers of susceptibility are recognized for some of the CTD, but no information on the basis of which to evaluate them was available in the epidemiologic studies. In addition, many studies did not report whether the indication for implantation was cosmetic or reconstructive, a difference that may have affected the signs and symptoms the subjects subsequently had.

Publication bias could be considered because studies that found no association between exposure and disease were less likely to be submitted and accepted for publication than were studies that found a positive association. 
We realize that the present review has several limitations, but we believe that our findings may help physicians, such as general practitioners, plastic surgeons and internists, to recognize the systemic symptoms or unexplained symptoms pattern in women with silicone $\mathrm{Bl}$ and so provide clinical information to enable a better practice and personal choice.

From a public health perspective, breast implants appear to have a minimal effect on the number of women in whom autoimmune diseases develop and elimination of implants would be unlikely to reduce the incidence of them.

\section{CONCLUSION}

Despite the controversy, evidence remains inconclusive about any association between BI and classical autoimmune diseases. We will need better evidence from large studies, with long time follow-up and with accurate methodology to determine whether any true association exists between ASIA syndrome and silicone breast implants.

CONFLICTS OF INTEREST: The authors declare that they have no conflicts of interest.

FINANCIAL SUPPORT: This work has not received any contribution, grant or scholarship.

CONFLITOS DE INTERESSE: Os autores declaram a inexistência de conflitos de interesse na realização do trabalho.

FONTES DE FINANCIAMENTO: Não existiram fontes externas de financiamento para a realização deste artigo.

PREVIOUS PRESENTATIONS: This work has not received any contribution, grant or scholarship.

\section{REFERENCES}

1. Balk EM, Earley A, Avendano EA, Raman G. Long-Term Health Outcomes in Women With Silicone Gel Breast Implants: A Systematic Review. Ann Intern Med. 2016;16:164-75.

2. FDA Update on the Safety of Silicone Gel-Filled Breast Implants. Center for Devices and Radiological Health U.S. washington: Food and Drug Administration; 2011.

3. Maijers MC, de Blok CJM, Niessen FB, van der Veldt A a. M, Ritt MJPF, Winters $\mathrm{H}$ a. $\mathrm{H}$, et al. Women with silicone breast implants and unexplained systemic symptoms: a descriptive cohort study. Neth J Med. 2013;71:534-40.

4. Jara LJ, García-Collinot G, Medina G, Cruz-Dominguez MD, Vera-Lastra O, Carranza-Muleiro RA, et al. Severe manifestations of autoimmune syndrome induced by adjuvants (Shoenfeld's syndrome). Immunol Res. 2016 (in press).

5. Colaris MJL, de Boer M, van der Hulst RR, Cohen Tervaert JW. Two hundred cases of ASIA syndrome following silicone implants: a comparative study of 30 years and a review of current literature. Immunol Res. 2016 (in press).

6. Cohen Tervaert JW, Kappel RM. Silicone implant incompatibility syndrome (SIIS): a frequent cause of ASIA (Shoenfeld's syndrome). Immunol Res. 2013;56:293-8.

7. Goren I, Segal G, Shoenfeld Y. Autoimmune/inflammatory syndrome induced by adjuvant (ASIA) evolution after silicone implants. Who is at risk? Clin Rheumatol. 2015;34:1661-6.

8. Janowsky EC, Kupper LL, Hulka BS. Meta-analyses of the relation between silicone breast implants and the risk of connective-tissue diseases. N Engl J Med. 2000;342:781-90.

9. Hennekens CH, Lee IM, Cook NR, Hebert PR, Karlson EW, LaMotte F, et al. Self-reported breast implants and connective-tissue diseases in female health professionals. A retrospective cohort study. JAMA. 1996;275:616-21.

10. Shoaib BO, Patten BM, Calkins DS. Adjuvant breast disease: an evaluation of 100 symptomatic women with breast implants or silicone fluid injections. Keio J Med. 1994;43:79-87. 